Victor J. Sedubun, Kajian Filsafat Hukum ....

\title{
KAJIAN FILSAFAT HUKUM TENTANG \\ PEMBENTUKAN PERATURAN DAERAH
}

\author{
Oleh : Victor Juzuf Sedubun
}

\begin{abstract}
Establishment of regulations in the area causing problems when the rule is applied. Some parties feel that the rules are there to organize and manage the region carried out only for the interests of certain groups. The fact that there are not any products that regulation can work well because the cause of conflict in society. Resulting in the cancellation of a regional regulation.
\end{abstract}

Keywords: Essentials of Local Regulations

\section{A. LATAR BELAKANG.}

Salah satu unsur dalam agenda reformasi adalah penerapan sistem desentralisasi sebagai bentuk pemerintahan dalam penyelenggaraan pemerintahan di daerah kabupaten dan kota. Melalui penerapan sistem desentralisasi, diharapkan daerah mampu mengatur dan mengurus rumah tangganya sehingga tujuan perubahan sistem pemerintahan daerah, yaitu adanya peningkatan taraf kehidupan masyarakat di daerah dan kesejahteraan daerah serta terciptanya sistem pemerintahan daerah yang lebih baik dapat tercapai. Dalam kaitan tersebut, derah dituntut harus kreatif dalam menangani dan mengelola sumber daya, baik itu sumber daya alamnya maupun sumber daya manusianya yang dimiliki daerah. Dengan kreativitas yang dimiliki masing-masing daerah, diharapkan daerah mampu melakukan pembaharuan untuk meningkatkan kesejahteraan masyarakat di daerah masing-masing dan memajukan daerah itu sendiri.

Harapan akan perubahan melalui pemberlakuan desentralisasi tidak serta merta mampu mengatasi krisis sosial ekonomi masyarakat, melainkan perubahan pasca reformasi yang berlangsung demikian cepat, menimbulkan permasalahan baru. Berbagai penafsiran dan pemaknaan yang keliru terhadap desentralisasi dikemukakan oleh banyak pihak, baik oleh aparatur penyelenggara pemerintahan di pusat maupun di daerah (legislatif maupun eksekutif), para akademisi maupun tokoh/pemuka masyarakat (adat, agama maupun budaya), yang berakibat pada timbulnya berbagai polemik dalam masyarakat. Masyarakat merasa penerapan prosedur administrasi yang oleh pemerintah terlalu berbelit-belit dan kontrol yang ketat. Masyarakat merasa bahwa kepentingan masyarakat yang hidup dan berkembang dalam praktek kehidupan selama ini harus diakomodir semuanya dalam peraturan perundang-undangan. Penataan potensipotensi daerah oleh pemerintah daerah yang diberikan hak untuk membentuk produk peraturan daerah. Pembentukan peraturan bertujuan untuk mengakomodir kepentingan dan kebutuhan daerah dengan memperhatikan kepentingan masyarakat dan ciri khusus yang dimiliki daerah tidak berjalan dengan baik.

\section{B. METODE PENULISAN}

Metode yang digunakan dalam penulisan adalah dengan menggunakan tipe penelitian hukum normatif, yakni mengkonsepsikan hukum sebagai norma, 
kaidah, asas, atau dogma-dogma, dengan menggunakan pendekatan perundangundangan atau Statute Approach ${ }^{l}$ yang dijelaskan secara deskriptif berdasarkan permasalahan dengan berbagai aturanaturan hukum dan literatur, serta mencari suatu opini hukum tentang masalah yang menjadi objek permasalahan.

\section{PEMBAHASAN}

\section{Kewenangan Pemerintah Daerah Membentuk Peraturan Daerah}

Secara etimologis, kata desentralisasi berasal dari bahasa Latin, yaitu de yang berarti lepas dan centrum yang berarti pusat. Desentralisasi adalah melepaskan diri dari pusat. United Nations (1962 : 3) decentralization refers to the transfer of authority away from I be nation capital wethwe by deconcenlralion (i. e. delegation) to field offices or by devolution to local authorities or local bodies. Konsep tersebut menunjukkan bahwa Desentralisasi proses kewenangan yang diserahkan pusat kepada daerah melalui cara delegasi kepada pejabat-pejabatnya didaerah atau dengan devolusi kepada badan-badan otonom daerah. Sementara itu, dalam Encylopedia of the Social Sciences disebutkan bahwa the process of decentralization denotes the transference of authority, legislative, judicial or administrative, from higher level of government to alower (Desentralisasi adalah penyerahan wewenang dari tingkat Pemerintahan yang lebih tinggi kepada Pemerintahan yang lebih rendah, baik yang menyangkut bidang legislative, judikatif atau administratif). Sedangkan otonomi berasal dari bahasa Yunani, auto yang berarti sendiri dan nomous yang berarti hukum atau peraturan, yang dapat diartikan secara harafiah otonomi dapat berarti

1 Peter Mahmud Marzuki; Penelitian Hukum; Jakarta; Kencana Prenada Media Group; 2005; hal. 96 hukum atau peraturan sendiri. Menurut Encyclopedia of Social Science, otonomi dalam pengertian orisinil adalah the legal self sufficiency of social body and its actual indenpendence. Dalam pengertian ini ada 2 (dua) ciri hakekat dari otonomi yakni legal self sufficiency dan actual indenpendence. Selanjutnya dikatakan bahwa dalam kaitannya dengan politik atau pemerintahan, otonomi daerah berarti self government atau condition of living under one's own laws. Dengan demikian dengan adanya otonomi daerah, daerah yang memiliki kecakapan diri secara hukum (legal self Sufficiency) yang bersifat pemerintahan sendiri (self government) yang diatur oleh hukum sendiri (ownlaws).

$$
\text { Melalui penerapan sistem }
$$

desentralisasi, diharapkan daerah mampu mengatur dan mengurus rumah tangganya sehingga tujuan perubahan sistem pemerintahan daerah, yaitu adanya peningkatan taraf kehidupan masyarakat di daerah untuk mencapai kebahagiaan yang diharapkan setiap individu dapat tercapai. Dalam kaitan tersebut, derah dituntut harus kreatif dalam menangani dan mengelola sumber daya, baik itu sumber daya alamnya maupun sumber daya manusianya yang dimiliki daerah. Dengan kreativitas yang dimiliki masing-masing daerah, diharapkan daerah mampu melakukan pembaharuan untuk meningkatkan kesejahteraan masyarakat di daerah masing-masing dan memajukan daerah itu sendiri. Desentralisasi diharapkan mampu menjadi salah satu alat untuk mengatasi krisis di daerah. Berbagai potensi perubahan sosialekonomi yang ada dalam masyarakat harus didorong oleh pemerintah daerah, sehingga potensi itu dapat membantu daerah keluar dari krisis.

Dalam konteks hubungan antara pusat dengan daerah, sistem penyelenggaraan pemerintahan daerah bergeser dari sistem yang sentralistik menjadi sistem yang mengedepankan otonomi dengan berpijak pada prinsip desentralisasi. Penerapan prinsip desentralisasi sebagai dasar berpijak 
penyelenggaraan pemerintahan daerah membangun konstelasi baru sistem otonomi daerah yang luas, nyata, dan bertanggung jawab yang memberikan hak dan wewenang kepada daerah otonom untuk mengatur dan mengurus sendiri urusan pemerintahan dan kepentingan masyarakat setempat sesuai dengan peraturan perundang-undangan.

Sebagai dasar dalam penyelenggaraan pemerintahan daerah, maka peraturan daerah merupakan suatu tuntutan dari adanya hubungan antara pusat dan daerah dalam bentuk negara kesatuan berdasarkan prinsip otonomi. Penyelenggaraan pemerintahan di daerah dengan menjabarkan ketentuan dalam peraturan perundang-undangan menghendaki adanya peraturan daerah yang sesuai dengan potensi dan keragaman daerah. Penyelenggaraan pemerintahan daerah berdasarkan Undang-Undang Nomor 32 Tahun 2004 memungkinkan pemerintah daerah dapat menetapkan peraturan daerah dalam batas kewenangannya, di bawah supervisi dan pengawasan ketat dari Pemerintah.

Penataan potensi-potensi daerah oleh pemerintah daerah yang diberikan hak untuk membentuk produk peraturan daerah. Pembentukan peraturan bertujuan untuk mengakomodir kepentingan dan kebutuhan daerah dengan memperhatikan kepentingan masyarakat dan ciri khusus yang dimiliki daerah tidak berjalan dengan baik. Kepentingan masyarakat secara umum harus dapat ditata oleh pemerintah daerah melalui peraturan yang dibentuknya sehingga masyarakat dapat hidup dengan tertib dan damai. Pembentukan Peraturan Daerah mestinya juga memperhatikan dan mengacu pada peraturan-peraturan lain yang dalam hierarki peraturan perundangundangan memiliki kedudukan yang lebih tinggi dari Peraturan Daerah. Hal ini dimaksudkan untuk tidak memberikan dampak pada pembatalan terhadap Peraturan Daerah yang bentuk, karena bertentangan daengan kepentingan umum dan peraturan perundang-undangan yang lebih tinggi.

Berkaitan dengan kepentingan masyarakat tersebut, maka Peraturan Daerah sebagai produk hukum di daerah seharusnya mengakomodir kepentingan masyarakat. Materi muatan Peraturan Daerah mestinya menjawab kebutuhan masyarakat untuk mencapai kebahagiaan, sehingga daerah harus kreatif dalam menata semua potensi yang dimilikinya untuk dikelola oleh semua masyarakat guna mencapai kebahagiaan itu. Kebahagiaan masyarakat pada kenyataan bukan saja merupakan ucapan oral semata, namun wujud kebahagiaan itu adalah kepemilikan dari masyarakat. Masyarakat akan merasa bahagia jika ia memiliki sesuautu dari apa yang diupayakannya.

$\begin{array}{crr}\text { Peraturan } & \text { Daerah } & \text { memiliki } \\ \text { kedudukan yang } & \text { strategis } & \text { dalam }\end{array}$ penyelenggaraan pemerintahan bagi suatu daerah otonom berdasarkan prinsip otonomi dan tugas pembantuan. Dasar konstitusionalitas Peraturan Daerah sebagai produk hukum daerah merupakan atribusi kewenangan yang didasarkan pada Pasal 18 ayat (6) Undang-Undang Dasar Negara Republik Indonesia Tahun 1945 (selanjutnya disebut UUD 1945) yang menyebutkan bahwa: "Pemerintahan daerah berhak menetapkan peraturan daerah dan peraturan-peraturan lain untuk melaksanakan otonomi dan tugas pembantuan".

Dalam menyelenggarakan roda pemerintahan, maka bagi daerah diperlukan dasar hukum yang menjadi landasan bagi daerah dalam penyelenggaraan pemerintahan daerah. Penyelenggaraan pemerintahan daerah sebagai kewenangan daerah pun dilaksanakan berupa kewenangan daerah untuk menetapkan peraturan daerah. Sudah tentu kewenangan pembentukan peraturan daerah ini terkait dengan kewenangan pemerintah daerah dalam penyelenggaraan seluruh urusan pemerintahan yang diserahkan kepada daerah. Itu berarti, melalui peraturan daerah, pemerintah daerah dapat melakukan 
tindakan-tindakan tertentu yang terkait dengan bidang pemerintahan, pembangunan dan pelayanan masyarakat.

\section{Hakekat Pembentukan Peraturan Daerah}

Pembentukan hukum tersebut harus didasarkan pada kebenaran fakta yang terjadi dalam masyarakat. Berdasarkan kebenaran fakta tersebut pembentukan hukum harus dapat memenuhi kebutuhan masyarakat terhadap suatu aturan tertentu yang mengendalikan perilaku individu dalam masyarakat. Menurut Samuel ${ }^{2}$ dalam bukunya Epistemology and Method in Law, mengemukakan bahwa pengetahuan hukum terdiri dari pengetahuan tentang aturan dan pengetahuan tentang konstruksi fakta. Objek ilmu hukum adalah model hukum dibangun dari fakta-fakta. Gagasan bahwa fakta-fakta cara dibangun secara internal menuju cara yang mereka demikian dipandang, mampu menciptakan dimensi normatif yang terpisah dari aspek normatif yang terikat pada aturan hukum. Konstruksi ini sebenarnya bisa dilihat sebagai semacam precategorisation sebelum fakta-fakta secara resmi ditugaskan ke kategori hukum yang didirikan. Bagaimana fakta sebenarnya dibangun pada tahap pra kategorisasi mungkin menjadi langkah aktif dalam proses mencapai solusi dalam kasus dan dengan demikian pembangunan - dan rekonstruksi - fakta-fakta sama pentingnya dengan mencari apapun, atau suatu aplikasi, aturan . Fakta-fakta dari kasus tidak fakta nyata. Mereka tidak situasi kehidupan nyata, tetapi kenyataan virtual karena objek ilmu hukum bukanlah fenomena dunia nyata (fakta-fakta nyata dari kasus).

Selanjutnya Samuel mengemukakan bahwa peran lembaga-lembaga hukum dan konsep merupakan pusat penyelidikan epistemologis dan metodologis hukum, dalam arti bahwa mereka bertindak sebagai

2 Geofferey Samuel. 2007. Epistimology and Method in Law. Kent Law School, UK, Juridishe Bibliotheek University Utrecht. p. 115 jembatan antara dunia hukum dan fakta sosial. Ada tiga instansi fundamental: orang (persona), hal (res), dan tindakan (actio). Lembaga-lembaga ini bertindak sebagai tiga elemen struktur utama atau titik pelabuhan dalam suatu model dimana hubungan antara unsur-unsur yang memberikan ekspresi dengan sifat struktural dan spasial dari citra faktual. konsep hukum adalah model di mana itu adalah hubungan antara unsur-unsur yang memberikan ekspresi dengan sifat struktural dan spasial dari citra faktual.

Pound dalam bukunya $A n$ introduction to the Philosopy of Law, mengemukakan bahwa terdapat dua macam kebutuhan telah mendorong pemikiran filsafat tentang hukum. Pada satu pihak, kebutuhan masyarakat yang besar akan keamanan umum, yang sebagai suatu kebutuhan akan adanya perdamaian dan ketertiban telah mendiktekan asal-usul dari hukum, telah mendorong manusia untuk mencari suatu dasar yang pasti berupa suatu aturan tertentu mengenai tindakan manusia yang dapat membendung tindakan sewenang-wenang baik dari hakim maupun individu, untuk akhirnya dapat mendirikan suatu susunan masyarakat yang teguh dan mantap. Pada lain pihak tekanan dari kepentingan masyarakat yang tidak begitu mendesak, dan kebutuhan untuk menyesuaikannya dengan kebutuhankebutuhan di bidang keamanan umum dan untuk secara tak henti-henti membuat kompromi-kompromi baru karena terjadi perubahan terus menerus dalam masyarakat telah selalu mengharuskan dilakukannya penyesuaian-penyesuaian, setidak-tidaknya mengenai rincian-rincian dari susunan masyarakat.

Demikianlah para filsuf telah mencoba untuk menyusun teori-teori tentang hukum dan teori-teori tentang pembuatan hukum dan telah berusaha untuk mempersatukannya dengan menggunakan gagasan yang dapat memecahkan pokok persoalannya, seimbang dengan tugas untuk menghasilkan suatu hukum yang sempurna yang dapat berdiri terus-menurus untuk 
selama-lamanya. Sejak saat pada waktu para pembentuk undang-undang melepaskan percobaan untuk mempertahankan keamanan umum, karena keyakinan bahwa kumpulan-kumpulan khusus dari hukum manusia telah diperintahkan oleh kekuasaan Illahi atau diwahyukan oleh kekuasaan Illahi atau diberi sanksi oleh kekuasaan Illahi, mereka telah bergelimang dengan masalah untuk membuktikan kepada manusia bahwa hukum itu adalah sesuatu yang pasti dan tentu. Bahwa kekuasaannya tidak dapat dipersoalkan lagi, meskipun pada saat yang bersamaan mungkin baginya untuk mengadakan penyesuaian secara tetap dan sekali-kali untuk mengadakan perubahanperubahan yang radikal karena adanya tekanan dari keinginan-keinginan manusia yang sifatnya tidak terbatas dan selalu berubah. $^{3}$

Hukum adalah perintah penguasaan negara. Hakikat hukum menurut John Austin terletak pada unsur perintah. Hukum dipandang sebagai suatu sistem yang tetap, logis, dan tertutup. Karena itu, pihak penguasalah yang menentukan apa yang diperbolehkan dan yang tidak diperbolehkan. Kekuasaan dari penguasa dapat memberlakukan hukum dengan cara menakuti dn mengarahkan tingkah laku orang lain ke arah yang diinginkan.

John Austin, pada mulanya, membedakan hukum dalam dua jenis, yaitu hukum dari Tuhan untuk manusia dan hukum yang dibuat oleh manusia dapat dibedakan dengan hukum yang sebenarnya dan hukum yang tidak sebenarnya. Hukum yang sebenarnya inilah yang disebut sebagai hukum positif yang meliputi hukum yang dibuat oleh penguasa dan hukum yang disusun oleh manusia secara individual untuk melaksanakan hak-hak yang diberikan kepadanya. Hukum yang tidak sebenarnya adalah hukum yang tidak dibuat oleh penguasa sehingga tidak memenuhi

\footnotetext{
3 Roscoe Pound. 1954. An Introduction to the Philosophy of Law. Yale University. New Haven and London
}

persyaratan sebagai hukum. Hukum yang sebenarnya memiliki empat unsur yaitu perintah (Command), sangsi (sanction), kewajiban (duty), dan kedaulatan (soveignty).

Sementara menurut Hans Kelsen, hukum harus dibersihkan dari anasir-anasir non yuridis seperti unsur sosiologis, politis, historis, bahkan nilai-nilai etis. Pemikiran inilah yang dikenal dengan teori hukum murni (reine rechlehre). Jadi hukum adalah suatu kategori keharusan (sollens kategorie) bukan kategori factual (sains kategorie). Hukum baginya merupakan suatu keharusan yang mengatur tingkah laku manusia sebagai makhluk rasional.

Teori hukum murni boleh dilihat bagai suatu pembangunan yang amat seksama dari aliran positivisme. Ia menolak ajaran yang bersifat ideologis dan hanya menerima hukum sebagaimana adanya, yaitu dalam bentuk peraturan-peraturan yang ada. Teori hukum ini adalah teori tentang hukum positif. Ia berusaha untuk mempersoalkan dan menjawab pertanyaan apakah hukumnya dan bukan bagaimana hukum yang seharusnya. Karena itu, menurut Hans Kelsen keadilan sebagaimana lazimnya dipertanyakan hendaknya dikeluarkan dari ilmu hukum. Ia adalah suatu konsep. Ideologis, suatu ideal yang irasional. Pendapat yang mengemukakan bahwa keadilan itu ada, ternyata tidak dapat memberikan batasan yang jelas sehingga menimbulkan keadaan yang kontradiktif. Bagaimanapun keadilan itu tidak dapat dilepaskan dari kehendak dan tindakan manusia. Ia tidak bisa menjadi subjek ilmu pengetahuan. Apabila dipandang dari sudut pengetahuan rasional, yang ada hanya kepentingan-kepentingan. Oleh karena itu, hanya ada konflik kepentingan-kepentingan.

Dasar-dasar pokok pikiran teori Hans Kelsen adalah sebagai berikut: pertama, tujuan teori tentang hukum, seperti juga setiap ilmu adalah untuk mengurangi kekalutan dan meningkatkan kesatuan (unity); kedua, teori hukum adalah ilmu, bukan kehendak, keinginan. Ia adalah 
pengetahuan tentang hukum yang ada bukan tentang hukum yang seharusnya ada; ketiga, ilmu hukum adalah normatif bukan ilmu alam, keempat, sebagai suatu teori tentang hukum adalah formal, suatu teori tentang cara pengaturan dari sisi yang berubah-ubah menurut jalan atau cara yang spesifik, dan keenam, hubungan antara teori hukum dengan suatu sistem hukum positif tertentu adalah seperti antara hukum yang mungkin dan hukum yang ada.

Hans Kelsen juga dikenal sebagai pencetus teori berjenjang, (stuffen theory) teori ini melihat hukum sebagai suatu sistem yang terdiri dari susunan norma berbentuk piramida. Norma yang lebih rendah memperoleh kekuatan dari suatu norma yang lebih tinggi. Semakin tinggi suatu norma akan semakin abstrak sifatnya dan sebaliknya semakin rendah kedudukannya akan semakin kongkrit. Norma yang paling tinggi menduduki puncak piramida yang disebut norma dasar (grund norm). teori berjenjang ini kemudian dikembangkan oleh Hans Nawasky. Namun, lebih mengkhususkan pada pembahasan norma hukum saja. Sebagai penganut dari aliran positif, hukum dipahami identik dengan perundangundangan yang dikeluarkan oleh penguasa.

Hukum harus dinamis, tidak boleh statis dan harus memberikan perlindungan kepada masyarakat. Hukum harus dapat dijadikan penjaga ketertiban, ketenteraman dan pedoman tingkah laku dalam kehidupan masyarakat. Hukum harus dapat dijadikan pembaharu dalam kehidupan berbangsa dan bernegara yang harus dibentuk dengan berorientasi kepada masa depan, hukum tidak boleh dibangun dengan berorientasi kepada masa lampau. Oleh karena itu, hukum harus dapat dijadikan pendorong dan pelopor untuk menata dan bila perlu mengubah kehidupan masyarakat kepada yang lebih baik dan bermanfaat untuk semua pihak.

Pada tahapan kemapanan hukum hukum dipandang sebagai sesuatu yang memadai dengan sendirinya, gagasan hakhak alami tampak menjelaskan secara kebetulan apa tujuan hukum dan memperlihatkan bahwa seharusnya terdapat sedikit mungkin tujuan hukum, karena itu adalah hambatan pada kebebasan dan bahkan hambatan yang paling kecil tersebut memerlukan pembenaran yang tegas. Jadi terlepas dari peningkatan secara sistematis dan formal, teori pembuatan hukum pada tahap kemapanan hukum adalah negatif. Hal itu terutama menyampaikan kepada kita bagaimana kita tidak boleh melakukan legislasi dan tentang persoalan-persoalan apa kita harus menahan diri untuk pembuatan hukum. Pound melihat bahwa meskipun tidak mempunyai teori pembentukan hukum yang positif, sehingga pada abad kesembilan belas kecil kesadaran mengharuskan atau menganut teori tentang tujuan hukum, dalam kenyataannya abad tersebut menganut teori tujuan hukum dan menganutnya secara teguh.

Pound melihat bahwa gagasangagasan mengenai tujuan hukum pada masa itu sebagian besar tersirat dalam gagasangagasan tentang apakah hukum itu.tentang Tujuan Hukum, dibahas 12 konsepsi tentang hukum. Selanjutnya Pound mengemukakan gagasannya mengenai tujuan hukum. Gagasan Pound mengenai tujuan hukum ada 3, yaitu:

1. Pada tingkatan hukum primitif, hukum diadakan supaya terjaga ketenteraman di dalam suatu masyarakat tertentu, untuk menjaga Peraturan Daerahmaian dalam keadaan bagaimana saja dan dipelihara dengan mengorbankan apa saja.

2. Menjaga perdamaian dan ketertiban hukum masyarakat.

3. Pemeliharaan status quo dalam masyarakat, yang menjadi konsepsi tujuan hukum pada bangsa Yunani, Romawi, dan bangsa bangsa Eropa pada abad pertengahan.

Murphy $^{4}$ juga memberikan pandangannya mengenai tujuan hukum. Menurut Murphy, tujuan hukum adalah untuk memberikan kebaikan bersama,

\footnotetext{
${ }^{4}$ Murphy, Mark. C. 2007. Philosophy of Law, The Fundamentals, Blackwell Publishing. p. 16
} 
walaupun pada akhirnya Murphy dianggap kurang konsisten karena dalam bab 1 pada bukunya Philosophy of Law the Fundamentals, Murphy mengatakan bahwa tujuan hukum adalah menekankan untuk kebaikan bersama (tanpa ada pilihan lain) namun dalam bab 3, Murphy memberi pilihan terhadap tujuan hukum itu sendiri yakni dengan mengolongkan antara tujuan hukum dan kebaikan bersama.

Menurut Kant ${ }^{5}$, hidup dalam arti sesungguhnya tidak terbatas pada apa yang dipraktekkan sehari-hari, tetapi harus dibedakan antara apa yang ada dan apa yang seharusnya ada. Yang seharusnya ada inilah yang menjadi norma untuk bertindak. Kita tidak dapat hidup begitu saja dan menerima setiap praktek sebagaimana adanya, karena jika demikian, maka apa yang ada akan diterima sebagai hukum meskipun bersisat destruktif. Kant juga mengatakan bahwa manusia dengan bantuan rasio harus mampu menempatkan ideal hidupnya melampaui apa yang ada. Dengan kata lain, fakta tidak dapat sertamerta menjadi norma.

Adanya hukum yang berfungsi sebagai norma untuk mengatur relasi antar anggota masyarakat membuat manusia terikat dengan kewajiban dan tanggung jawab hukum. Keterikatan ini juga disebut kewajiban hukum (legal responsibilty). Keterikatan legal ini menjadi urgen karena faktanya bahwa manusia selalu hidup bersama orang lain. Eksistensi manusia adalah koeksistensi. Manusia tidak dapat hidup tanpa orang lain. Hidup bersama orang lain dengan hak, kepentingan dan tuntutan yang berbeda-beda adalah kenyataan eksistensial. Keberagaman hak dan kepentingan serta ideal hidup berpotensi melahirkan konflik.

Lebih dari itu, keterikatan legal juga menjadi penting karena manusia menemukan dirinya tidak semata-mata

\footnotetext{
${ }^{5}$ Immanuel Kant. 1965. Metaphysical Elements of Justice, dalam Andre Ata Ujan. 2009. Filsafat Hukum, Membangun Hukum, Membela Keadilan. Kanisius. Yogyakarta. h. 29-30.
}

karena ia hidup untuk dirinya sendiri. Manusia menjadi berarti karena ia mau keluar dari dirinya dan menjadikan dirinya bermakna bagi orang lain. Dalam gaya paradox, manusia menjadi sempurna bukan karena ia terus berusaha menyempurnakan dirinya, melainkan karena ia terbuka membantu orang lain untuk berkembang dan menyempurnakan diri. Dalam interaksi aktif seperti inim keterikatan pada hukum sebagai norma perilaku menjadi penting karena ikatan moral saja pasti tidak mencukupi sebagai jaminan untuk membangun kerjasama yang saling menguntungkan di tengah kebaeragaman kepentingan.

Menurut Jeremy Bentham ${ }^{6}$, manusia akan bertindak untuk mendapatkan kebahagiaan yang sebesar-besarnya dan mengurangi penderitaan. Ukuran baik buruknya suatu perbuatan manusia bergantung pada apakah perbuatan itu mendatangkan kebahagian ataukah tidak. Atas dasar itu, maka Bentham berpendapat bahwa pembentuk undang-undang hendaknya melahirkan undang-undang yang dapat mencerminkan keadilan bagi semua individu. Dengan berpegang pada prinsip ini peraturan perundang-undangan hendaknya dapat memberikan kebahagiaan yang terbesar bagi masyarakat, hanya dalam ketertibanlah setiap orang akan mendapat kesempatan untuk mewujudkan kebahagiaan yang terbanyak, setiap orang bernilai penuh (volwaarding), tidak seorang pun bernilai lebih (everybody to count for one, no body for more than one).

Menurut Murphy ${ }^{7}$, satu cara untuk mengikuti pengajaran tentang gambaran Austin mengenai hukum adalah meyakinkan yang lainnya bahwa hukum mampu memenuhinya, membuat lebih jelas dan tepat, yang paling umum adalah masalah sosial. Ketika kita teringat akan masalah kenyataan sosial yang ada, kita harus yakin untuk melihat kenyataan sosial

\footnotetext{
${ }^{6}$ Friedmann, W. 1953. Legal Theory. Stevens and Sons Limited, $3^{\text {rd }}$ Edition. p. 403.

${ }^{7}$ Murphy, op.cit. p. 17-20
} 
kita harus menggunakan keberadaan hukum. Kita mungkin bisa menyarankan, dikatakan Austin, bahwa dimana terdapat hukum maka disitu terdapat perintah dan kepatuhan. Seperti halnya: jika anda tidak mengatakan pada orang lain apa yang harus dilakukan maka orang tersebut akan tetap melakukannya, maka anda tidak memiliki hukum. Jadi, dalam menghadapi kenyataan sosial yang ada dalam bertindak dan mematuhi kita memerlukan hukum.

Mari kita renungkan sejenak pengertian yang menjembatani bagaimana Austin mendefinisikan analisa mengenai pengalaman yang umum dan pemahaman tentang hukum. Hal ini terlihat benar ketika kita memasuki jenis hukum yang berupa seperti perintah (kita menggambarkan hukum seakan menyuruh kita melakukan apa yang dilakukan, memberi perintah atas kita dan seterusnya). Maka dari itu dikatakan bahwa Austin mampu menemukan sautu kesimpulan yang elegan untuk menjelaskan karakteristik dari hukum. Disisi kepatuhan, Austin dengan jelasnya mengatakan bahwa tidaklah cukup bagi orang - orang untuk mematuhi hukum pada satu kali waktu, atau sama seperti dua hal yang berbeda terjadi secara bersamaan. Kebiasaan untuk menjadi patuh pada orang yang lebih senior atau berkuasa. Maka, sebaiknya terdapat sebuah pembedaan antara hukum dan peraturan yang dibuat oleh orang tua untuk anaknya. Austin menyimpulkan bahwa hukum diberikan kepada orang-orang yang memiliki kebiasaan mematuhi peraturan. Sehingga hukum sendiri terdiri dari peraturanperaturan umum yang dipikirkan oleh para petinggi/pejabat-pejabat yang ahli dibidangnya. Sudut pandang mengenai gambaran atau karakteristik tentang hukum cukup menjanjikan. Apa yang seharusnya kita simpulkan mengenai fakta sosial yang berhubungan dengan kekuasaan dan tujuan hal yang baik.

Perhatikan, pada sudut pandang Austin, hukum menjadi ada karena adanya subyek yang mematuhinya karena rasa segan/hormat pada orang yang ditinggikan.
Dan juga dikatakan bahwa terdapat suatu kekuatan didalam hukum tersebut yang kita kenal dengan sanksi.

Menurut Murphy, Austin menjelaskan secara tidak langsung tentang hubungan hukum dengan tujuan yang baik, bahwa dimanapun hukum itu berada, hanya dibuat untuk kebaikan subyeknya. Hal ini sangatlah jarang sekali terjadi. Austin mencatat, bahwa hukum adalah tidak bijak, bodoh, membuang waktu, dan kuno. Dia menandai dengan pastinya, dan member contoh seperti hubungan antara hukum Tuhan dan manusia.

Sebagai penjelasan hubungan antara hukum Tuhan dan hukum manusia adalah saling bertentangan dan tidak terikat. Sebagai contoh sangatlah dilarang oleh para petinggi jika terdapat seseorang yang divonis hukuman mati, jika saya melakukan hal ini, dan saya menolak hukuman tersebut, hal ini bertentangan dengan hukum Tuhan. Pengadilan tidak akan menghiraukan alasan saya, dengan menggantung saya, sebagai ganjaran atas usaha saya membujuk hukum dimana saya meragukan nilai hukum.

Austin berpikir bahwa ini adalah hal yang biasa dari fakta sosial jika mungkin saja terdapat hukum-hukum dan yang setelah ini tidak menunjukkan contoh yang baik. Lalu, dapatkah Austin memenuhi hal yang harus diketahui khalayak umum bahwa hukum adalah bagi kepentingan bersama? Ia tidak memenuhinya dengan mengatakan bahwa tidak pernah ada hukum yang bertentangan dengan kepentingan bersama. Ia memenuhinya dengan memperlakukannya sebagai pembelajaran moral yang tegak lurus mengenai bagaimanakah seharusnya hukum itu. Menurut Austin, standar yang tepat adalah bahwa hukum harus dapat mencita-citakan apa yang sesuai dengan hukum yang berdasarkan ke Tuhanan. Berdasarkan pada prinsip-prinsip kebutuhan, hukum seharusnya dibuat dan diperbaharui dengan segala cara untuk memaksimalkan kesejahteraan sosial secara menyeluruh. 
Hasil karya H. L. A. Hart The Concept of Law mungkin adalah hasil karya terpenting dari filsafat hukum atas abad 20an. Efek penjelmaan dalam pelajaran ini secara besar-besaran dan dengan segera. Pandangan Hart, hukum adalah persoalan sosial, sebuah benda dari kehidupan sosial manusia, dan sebagai sebuah hasil tidak ada pembatas moral yang dibutuhkan atas apa yang berlaku sebagai hukum. Ia melafalkan sebuah konsep atas hukum alam yang sudah diberlakukan ke banyak garis-garis kecaman tetapi pada dasarnya masih terdengar.

Menurut Larry Alexander dan Emily Sherwin ${ }^{8}$, suatu peraturan itu harus memenui beberapa hal, yaitu: Pertama aturan yang dibuat harus peka terhadap keberadaan masyarakat dan menjawab kebutuhan masyarakat, tujuan diadakannya aturan adalah untuk menciptakan ketertiban dalam kehidupan masyarakat, sehingga pengakuan dan kebutuhan masyarakat harus mampu diakomodir oleh aturan tersebut. Kedua, dalam pendekatan positivisme, hal tersebut harus dapat dipertimbangkan untuk dimasukan dalam muatan materi aturan yang akan dibentuk. Ketiga, alasan eksklusioner. Menurut Joseph Raz, aturan hukum dapat dipahami sebagai alasan untuk bertindak, artinya aturan hukum berfungsi sebagai "perintah kedua" yang mengecualikan alasan mengatur "perintah pertama" proses pertimbangan moral. Keempat, sanksi. Cara yang memungkinkan untuk mempersempit kesenjangan adalah untuk menerapkan sanksi bagi yang melanggar aturan. Kelima, kecurangan. Merupakan salah satu alasan kekhawatiran terjadinya penipuan dalam aturan karena hal itu dapat mempengaruhi kualitas pembahasan masalah hukum dan moralitas.

\section{P E N U T U P}

8 Larry Alexander and Emily Sherwin. 2001. The Rule of The Rules, Morality, Rules, and the Dilemmas of Law. Duke University Press. Durham and London. p. 53-61.
Pembentukan hukum tersebut harus didasarkan pada kebenaran fakta yang terjadi dalam masyarakat. Berdasarkan kebenaran fakta tersebut pembentukan hukum harus dapat memenuhi kebutuhan masyarakat terhadap suatu aturan tertentu yang mengendalikan perilaku individu dalam masyarakat. Objek ilmu hukum adalah model hukum dibangun dari faktafakta. Gagasan bahwa fakta-fakta cara dibangun secara internal menuju cara yang mereka demikian dipandang, mampu menciptakan dimensi normatif yang terpisah dari aspek normatif yang terikat pada aturan hukum. Konstruksi ini sebenarnya bisa dilihat sebagai semacam precategorisation sebelum fakta-fakta secara resmi ditugaskan ke kategori hukum yang didirikan. Bagaimana fakta sebenarnya dibangun pada tahap pra kategorisasi mungkin menjadi langkah aktif dalam proses mencapai solusi dalam kasus dan dengan demikian pembangunan - dan rekonstruksi - fakta-fakta sama pentingnya dengan mencari apapun, atau suatu aplikasi, aturan. Fakta-fakta dari kasus tidak fakta nyata, mereka tidak dalam situasi kehidupan nyata, tetapi kenyataan virtual karena objek ilmu hukum bukanlah fenomena dunia nyata (fakta-fakta nyata dari kasus).

Dalam pendekatan penyerahan sebagaian urusan pemerintahan kepada penyelenggara pemerintahan di daerah, maka negara mengakui keberadaan daerah sebagai organ negara yang menjalankan urusan pemerintahan di daerah. Penyerahan urana tersebut sekaligus dengan penyerahan kewenangan pembentukan Peraturan Daerah kepada penyelenggara pemerintahan di daerah. Hakekat muatan materi Peraturan Daerah yang mengakomodir kepentingan masyarakat di daerah guna mencapai suatu kebahagiaan yang terbesar kepada masyarakat, mesti dihargai oleh penyelenggara pemerintahan di pusat sebagai urusan penyeleggara pemerintahan di daerah dalam mengupayakan kebahagiaan dan kesejahteraan kepada masyarakat di daerah. 
pengakuan tersebut pula maka daerah berhak menetapkan Peraturan Daerah untuk menampung kondisi khusus kepada daerah dan mengatur kehidupan bersama masyarakat di daerahnya dalam pergaulan antar individu. Dengan pengakuan itu, maka pemerintah di pusat tidak lagi dapat mengintervensi pembentukan Peraturan Daerah, sekalipun muatan materi Peraturan Daerah yang dibentuk oleh penyelenggara pemerintahan di daerah terdapat pertentangan dengan peraturan yang lebih tinggi, kecuali jika mutan materi tersebut bertentangan dengan konstitusi dan hakekat pembentukan Peraturan Daerah itu sendiri. Dengan demikian maka harus ada pengawasan preventif penyelenggara pemerintahan di pusat terhadap proses pembentukan Peraturan Daerah.

\section{DAFTAR PUSTAKA}

Alexander, Larry and Emily Sherwin. 2001. The Rule of The Rules, Morality, Rules, and the Dilemmas of Law. Duke University Press. Durham and London. p. 53-61

Bodenheimer, Edgar. 1970. The Philosophy and Method of The Law. $3^{\text {rd }}$ ed. Harvard University Press. Cambridge, Massachusetts.

Huijbers, Theo. 1982. Filsafat Hukum dalam Lintasan Sejarah. Kanisius. Yogyakarta.

1995. Filsafat Hukum, Kanisius, Yogyakarta.

Friedmann, W. 1953. Legal Theory. Stevens and Sons Limited, $3^{\text {rd }}$ Edition.

Kant, Immanuel. 1965. Metaphysical Elements of Justice.
Murphy, Mark. C. 2007. Philosophy of Law, The Fundamentals, Blackwell Publishing.

Parekh, Bhikhu. 2000. Rethinking Multiculturalism, Cultural Diversity and Political Theory. Palgrave. New York.

Posner, Richard A. 1993. The Problem of Jurisprudence, Havard University Press, Cambrigde, Massachusetts, London, England.

Postema, Gerald J. 1986. Bentham and the Common Law Tradition, Clarendon Press. Oxford. p. 403.

Pound,Roscoe. 1954. An Introduction to the Philosophy of Law. Yale University. New Haven and London.

Samuel, Geofferey. 2007. Epistimology and Method in Law. Kent Law School, UK, Juridishe Bibliotheek University Utrecht.

Undang-Undang Dasar Negara Republik Indonesia Tahun 1945. 